\title{
JUVENILE COURTS IN BUFFALO
}

\section{By Frederic Almy}

\author{
Secretary and Treasurer Charity Organization Society, Buffalo
}

Juvenile probation is no new thing. It has been used in Massachusetts since 1869 , or for over thirty years, and for the same length of time in that state a statute has required that children's cases should be "heard and determined by themselves, separate from the general and ordinary criminal business of said courts." There is no separate children's court in Massachusetts, but in some of the courts the session for adults is formally adjourned, and the room is cleared of all except those who have to do with the juvenile cases; in other courts the session for juveniles is held in a separate room or in the judge's private room. In either case there are evils, as is shown in a letter from Mr. Charles W. Birtwell, secretary of the Massachusetts Children's Aid Society: "Unfortunately in all the courts juveniles under arrest are apt to be mixed with adults while waiting during the hour or so preceding the trial. If not under arrest but only summoned, they may wait in the outside lobbies, but get more or less mixed with the throng about and in the court room."

The first juvenile court was opened in Chicago in I 899 and at once had wide notice, largely through the excellent work of the monthly periodical, the Chicago fuvenile Record. It was through this juvenile court that the probation system first became general. Mr. Folks tells us, in his "Care of Delinquent Children," that "the system did not secure formal adoption, so far as we are aware, in any other state than Massachusetts until the enactment of the juvenile court law in Illinois in I899." "In rgor," he says, "the probation system is in actual operation, or is provided for by statute, in fifteen of the twenty-five largest cities of the United States," and the number is now rapidly increasing. It is another instance of the contagion of ideas which in this century outstrips the contagion of disease.

On February 26, I 900 , the Buffalo Charity Organization Society appointed a committee on probation which held several meetings, but found that nothing could be done without legislation, 
which it was then too late to procure. A law passed May I, I9or, through the efforts of this committee, allowed the Buffalo police justice to suspend sentence with juvenile delinquents, and place them under probation for a term not exceeding three months. The act allowed him to appoint five unsalaried probation officers, and provided that when practicable the probation officer should be of the same faith as the child placed in his care. The court opened July I, I 901. By an amendment passed in February, I 902, the number of probation officers, still unpaid, was increased to ten, and authority was given to extend the probation for additional terms of three months in the discretion of the judge. A state probation law was also passed in $\mathrm{r} 90 \mathrm{I}$, but was so amended that it applied only to those over sixteen years of age. Consequently in New York State, outside of Buffalo, a chance is given to adult delinquents which is denied to little children.

Under the new New York City charter a juvenile court was created for the boroughs of Manhattan and Bronx (excluding Brooklyn), but with no provision for probation. This juvenile court was to open January I, I902, but for some reason did not do so.

Judge Murphy, of the Buffalo Police Court, was an active member of the committee of the Charity Organization Society which procured the probation law. Although the law was permissive only, he at once put it into effect, and also on his own motion transferred all his juvenile cases to a separate building, several blocks distant from the police court, where he holds his juvenile court on Tuesday and Friday afternoons. The great success of the court in Buffalo is chiefly due to his interest. Where for any reason a good judge is not available a juvenile court must suffer, for probation gives many opportunities for favoritism to both the judge and the probation officers. It is hardly too much to say that the character of the court will be the same as the character of the judge.

Of the ten probation officers in Buffalo all are unpaid for this special work, but two are truant officers, two are officers of the Charity Organization Society, and one is the head worker of Welcome Hall, a leading settlement. The city is divided into two districts, in each of which there are a Catholic and a Protestant female officer for the girls and the younger boys, and a Catholic and a Protestant male officer for the older boys. There are a Jewish officer and a Polish officer for the city at large. 
It is not perhaps desirable to recapitulate here the peculiarities of all the juvenile courts. In Massachusetts and St. Louis the probation officers are paid. In New Jersey the court costs are paid them. In Chicago, Pennsylvania, Milwaukee and Buffalo they are unpaid, or paid from private sources. In Chicago the probation is until the child's majority. In Boston, as in Buffalo, it is for short terms renewable on their expiration. It seems as if the short term would give the child a goal in sight and so help his striving.

The Buffalo juvenile court has not quite completed its first year, and no definite records have been compiled, but two results are already notable-the decrease in the number of commitments to the truant school and to reformatories, and the increase in the number of children arrested. The first result was expected, for many children are now cared for in their homes under probation who would otherwise have to be sent to the public truant school or to a reformatory. The second result was not anticipated, but is in this way excellent. Much juvenile lawlessness formerly ran riot without arrest because the officers knew that the judge would not send a child away for petty offences, and mere rebuke meant so little that the child fresh from court would jeer at the officer who had arrested him. With probation an arrest is taken more seriously by the children. At a recent session of the court Judge Murphy called attention to this increase in the number of arrests, and recommended legislation which should make convictions in the juvenile court inadmissible as evidence of character in either civil or criminal actions, so that mere juvenile peccadilloes could not constitute a criminal record.

The economy of probation greatly reinforces the support of the system on ethical grounds. It is not often that a measure of social reform makes an immediate appeal to the taxpayer, but probation relieves him from the public maintenance of many delinquents who under this plan are maintained at home at their parents' charge. In Massachusetts, where probation has been in operation many years, the district attorney has prepared figures showing that it has saved the state much more than the cost of its operation, though it is administered there by salaried probation officers. On the side of morality the saving is still greater, though less definite. If this saving of character could be translated into dollars and cents the cash gain to the state through the 
diminution of crime would be seen to be even greater than the saving in maintenance.

Again, the presence daily in the court of a group of disinterested men and women of character helps to maintain the moral tone of the court. They sometimes see things which the court unaided might not see. More than once in Buffalo pettifogging lawyers, who have been reaping fees from parents on the pretence that their services caused the judge to put children on probation instead of sending them away, have been excluded from the court on report of the probation officers as to their practices.

The teachers usually co-operate willingly in filling out the weekly cards which show the behavior and the attendance of a child while on probation, and they use their influence to hold children to their best. Some have spoken with wonder of the favorable effect of probation on the school work.

$A$ day in a juvenile court is fascinating, and the experiences of a probation officer are not less so. The little, curly-headed culprits are so anxious to tell their story to the judge, or sometimes so stolid, that either way it is pathetic. There is much weeping when children are found guilty, and sudden relief when the meaning of probation is explained to them, and the confidences made to the probation officer are irresistible. In many of the courts the proceedings are quite informal, and the children stand close to the judge and talk confidentially with him, without fear.

The care taken to keep children from contact with the adult criminal courts extends also to the jail. In several states the law prescribes that children shall not be lodged either in the jail or in the police court. If the child is unable to give bail, some place other than the jail or police court must be provided. In Pennsylvania a separate act, passed after the juvenile court law, authorizes the establishment of houses of detention. In Wisconsin it is provided that when a child has been sentenced he must be kept wholly apart from adult prisoners until he is committed. The period after arrest and before trial is also guarded.

It has been well said that the practice of arresting persons accused of minor offences, who are not in the least likely to fail to appear if merely summoned, is a relic of earlier times and should be abandoned. In Buffalo it is the general practice on arrest to take the child to a station-house and then let him go home under 
promise to appear in court at the time stated, and as yet the e has been no failure to appear.

Criminal law has relied too much upon confinement and compulsion, both of which involve cost to the state and rancor and sullenness in the individual. The features of probation are first, the retention of natural conditions, in the home, if it is at all fit, and second, loving, patient, personal service. Instead of withdrawing the child from the environment in which it lives, it tries to assist that environment. It is possible to draw many analogies. In medicine we now give fewer drugs and rely on the natural powers of the body with the personal service of trained nurses. In charity we give fewer alms, and rely on the natural resources of the family with the personal service of trained friendly visitors. In government we use less law, but rely on natural forces with the aid of the Church, the school and other instruments of social reform.

With children the question of reformation is especially important. The chief cause of crime has been said to be neither intemperance, nor avarice, nor lust, but neglected childhood, for neglected childhood means neglected character, and at an age when character is still plastic. Children under arrest for the first time are more peculiarly susceptible to influence than even other children, and the impressions made at this crisis go far to fix their lives. If you catch character young, and at the right moments, you can do almost anything with it. It is even possible to confine the baser parts of a child's life, as the Chinese do the feet of their children, so that the development of these baser parts will be permanently stunted. Swaddling environments, continued for years, can do much to form sharacter by compulsion, so to speak, and to thwart the growth of what is undesirable. This exclusion of evil is the method of the military school and of the reformatory of the military type. There is something unnatural about it, but there is no doubt that in this way habits can be formed; and there is an inertia of character which makes good habits difficult to break as well as bad ones.

The other method is to leave the natural conditions with as little disarrangement as possible; to let the feet grow and become a support for the whole body; to take the activity which might become crime and turn it into industry; to take the affection which might become lust and turn it into love; and to do all this as far as possible under natural conditions. It is possible to do 
this, not by a high wall which wards off all contamination but casts a shadow on the young ife within, but by applying some antiseptic which will make the contagions of daily life harmless. Those of us who with Milton “cannot praise a fugitive and cloister'd vertue, unexercis'd and unbreath'd," believe that everywhere character is better formed by liberty than by force. Antiseptics against temptation are being found by modern charity. I would wish to leave a child undisturbed in its home, if the home is decent, and trust to the Church, the school, the tenement house law and the settlements, as antiseptics against contamination; next to this I would leave the child at home, but under probation; next I would seek a foster home, well chosen and well watched; next, for some children, an open reformatory of the free type exemplified in the George Junior Republic; and last, a reformatory of the more military type. In confinement a boy may find himself kindly and wisely treated, but his social side is not much considered, and this is not in keeping with modern pedagogy. Very much can be done through a boy's affections.

Where the germ of pauperism or of vice cannot be killed, may there not be a treatment by antitoxin, as at the George Republic, by deliberately helping the poison to run its course in a mild form in order to prevent future attacks? It may be well to let a boy be idle and lazy for a time and suffer all the consequences of hunger and cold; to let him be violent, and as a penalty be duly and severely punished by his peers; in fact, to give him a brief rehearsal of life under natural conditions which will be very profitable when life arrives in grim earnest. These lessons are taught in a reformatory of the military type, but the more voluntary and natural the lesson is, and the more the child can be made to feel that he has chosen his own course and experienced its natural result, the deeper will be the impress on his life.

It seems to be the lesson of the past century, the lesson alike of charity, of Christianity, and of civilization, that, in forming character, force must give way to freedom with love. A militant Christianity has already been condemned, and a militant civilization is as bad. I believe in civilization by contact, in civilization by commerce, but not in civilization by conquest. Force leaves rancor and reaction, and the slower method of Christian example is more sure. The United States has been called the pioneer in an age of republics, but it is not through its force, but 
through its example, that in neither North nor South America is there to be found a king. The republics of Central and South America stumble and fall and make many errors, but they are slowly developing good secondary education and commercial stability. India and Egypt, with an original civilization and under as intelligent and benevolent tutelage as the world has ever known, are less fit to-day for self-government. With boy life as with national life, we may well stop to ask whether the least possible interference and the largest possible freedom, even with all the mistakes and struggles which this involves, will not build character most surely in the end. 